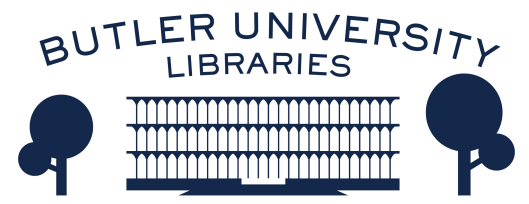

Journal of Hindu-Christian Studies

Volume 25

Article 17

November 2012

\title{
Book Review: "Piety and Responsibility: Patterns of Unity in Karl Rahner, Karl Barth and Vedanta Desika," John N. Sheveland
}

Reid B. Locklin

Follow this and additional works at: https://digitalcommons.butler.edu/jhcs

Part of the Religion Commons

\section{Recommended Citation}

Locklin, Reid B. (2012) "Book Review: "Piety and Responsibility: Patterns of Unity in Karl Rahner, Karl Barth and Vedanta Desika," John N. Sheveland," Journal of Hindu-Christian Studies: Vol. 25, Article 17.

Available at: https://doi.org/10.7825/2164-6279.1523

The Journal of Hindu-Christian Studies is a publication of the Society for Hindu-Christian Studies. The digital version is made available by Digital Commons @ Butler University. For questions about the Journal or the Society, please contact cbauman@butler.edu. For more information about Digital Commons @ Butler University, please contact digitalscholarship@butler.edu. 
Locklin: Book Review: "Piety and Responsibility: Patterns of Unity in Karl Rahner, Karl Barth and V edanta Desika," John N. Sheveland

70 Book Reviews

translated as 'essential nature/condition' and as an 'attribute that defines [Brahman's] essential nature', which might not have led the author to the conclusion that he does reach. This underscores the caution with which translated primary sources need to be utilized.

Chapters four and five discuss matter and the individual soul, which are dependent on Narayana/God. The comparison of the doctrine of liberation/salvation in chapter five addresses the topic of the state of the soul upon liberation. For Ramanuja, at the time of liberation, the individual self having detached from matter completely, gains back its essential nature, which was partially obscured by its contact with matter. Schleiermacher views redemption as a feeling (gefühl) of absolute dependence mediated through one's sensory self-consciousness. That is, salvation does not mean that the individual soul is completely separated from matter as in Ramanuja's case. Based on this distinction, Sydnor makes an intriguing speculation that the state of liberation in the Srivaisnava sense is "an amorphous collective consciousness", not individual enough, as all contact with matter through which one experiences is lost. However, according to Ramanuja, though the essential individuality of the soul upon liberation is of the nature of consciousness and this is common to all liberated souls, there is an essential individuality to the liberated souls, that he calls indescribable (agocara), and as something known to the selves themselves (svasamvedya). That is, Ramanuja does not eschew individuality between liberated selves,as the plurality of souls is accepted by him. A more in depth analysis of the differences in the definitions of consciousness, mind, sensory awareness, and feeling in the two traditions, would have added more depth to this discussion.

A very helpful conclusion clarifies the advantages and limitations of the constructive comparative methodology and offers a summary of the findings from previous chapters. Altogether, Sydnor's study is a stimulating work and a worthy addition to the growing field of comparative theology. His arguments are convincingly made and the study provides a number of insights into the nature of absolute dependence in the theologies of Ramanuja and Schleiermacher. This study will be of lasting value for scholars of both the Hindu and Christian traditions.

Sucharita Adluri

Cleveland State University

\section{Piety and Responsibility: Patterns of Unity in Karl Rahner, Karl Barth and Vedanta Desika. John N. Sheveland, Farnham, Surrey, England: Ashgate Publishing, 2011, 217 pages.}

RARELY are book titles so descriptive of the actual content of a work. In this volume, John Sheveland, Associate Professor of Religious Studies at Gonzaga University, takes up the theme of the twofold love of God ("piety") and love of neighbor ("responsibility") in the work of the modern Christian theologians Karl Rahner and Karl Barth and the late medieval Srivaisnava teacher Vedanta Desika. Sheveland's argument operates on two levels simultaneously. With regard to the three figures of his study, he employs "piety" and "responsibility" as "vague categories" in the style of Robert Neville to demonstrate a strong thread of unity-or, better, unity-indifference-on the mutual relation of these two loves. "The major thesis," he writes, "asserts an organic unity between the response of piety to God's revelation and the response's attending responsibility to body forth a life in the world transparent to its ground. It is not possible to have either piety or responsibility without the other" (3-4). At a second level of interpretation, precisely because each of his three subjects articulates this organic unity in ways specific to their theological and religious traditions, Sheveland argues that they are most fruitfully set into mutual relation according to 
an aesthetic, musical sensibility rather than a strictly theological or philosophical one. So he does not so much seek mutual agreement as illustrate a "harmony" of these three voices that opens, in its fullest extent, to a rich "polyphony."

The structure of the argument is nearly as transparent as the title, insofar as the three major body chapters (chs. 2-4) take up each of his three subjects' individual deployment of the two themes, in the context of their broader visions of religious life, particularly in the area of theological anthropology. Each is longer than the one that precedes it, so that the chapter on Vedanta Desika is almost twice the length of the chapter on Rahner. This is not simply because the implied audience is more familiar with modern Christian thought than with medieval Srivaisnavism, though this is one factor. Primarily, it is a function of the musical analogy itself.

The chapter on Rahner is, by and large, strict exposition, establishing what sheveland calls the "melody" of the piece. In the chapter on Barth he dedicates the final section to explicit comparison, noting differences in emphasis between the Catholic and the Protestant theologians, correcting common distortions of their respective positions and, above all, illustrating a fundamental "harmony" in the ways that both privilege the workings of divine grace without obscuring the integrity of the human response. Similar emphases are subsequently brought out in the exposition of Vedanta Desika, with more extended, "polyphonious" comparisons throughout chapter 4. By this method Sheveland illustrates how the Hindu and the Catholic show greater resonance on points such as inclusivity and ontological participation in the life of God, as well as how the Hindu and Protestant show greater resonance on points such as the importance of gratitude and "the vertical ordering principle governing the two loves" (201). He also brings out points distinctive to one or the other conversation partner, such as Barth's rich, "thick description" of human life in community (94101) and Rahner's particular concern with the universality and global character of Christian responsibility (195-98).
On the whole, the expositions are very strong and the comparisons responsible. Sheveland demonstrates an excellent command of both primary and secondary sources, and the footnotes reveal his animated engagement with contested questions of interpretation for all three figures. For this reason alone, the book recommends itself as a useful textbook for graduate students in Christian theology. At the same time, the work reads very much like a doctoral thesis, with some of the limitations that implies. The structure of the work lends itself to repetition, as key expositions of Rahner or Barth must be reintroduced each time the idiom shifts to explicit comparison. The introduction and conclusion are also rather thin, and Sheveland gestures only briefly at the relevance of his study for the distinctive challenges of contemporary life (e.g. 4, 202). Finally, although Rahner and Barth are obvious dialogue partners for historical reasons, the choice of Vedanta Desika as the representative Hindu interlocutor is less clear, defended primarily on the relatively simple basis that he "compares well" with them on the selected themes (10). The choices of any comparative theologian are inevitably at least a little bit arbitrary, and all three of sheveland's subjects here are of obvious, intrinsic value. Nevertheless, particularly in light of its several very fine expositions of the importance of the body and human community, the actual comparison in Piety and Responsibility may strike some readers as curiously disembodied.

In his conclusion, Sheveland indicates that his work is strictly descriptive, by design, oriented more to open up an aesthetic, imaginative space to practice theology than directly to "decide specific questions concerning truth claims" (202). This is in some ways a modest goal, despite its complexity, and one that can be counted a success. Given the strong commitments of all three of his interlocutors to theological specificity and the priority of divine revelation-Sheveland goes to great lengths, for example, to insist upon the Christological center of Rahner's theological project-one wonders how long such questions can be deferred and how they might be answered in the new, ecumenical and interreligious aesthetic context to which 
Locklin: Book Review: "Piety and Responsibility: Patterns of Unity in Karl Rahner, Karl Barth and V edanta Desika," John N. Sheveland

72 Book Reviews

Sheveland hopes to contribute with this book. One thing is certain: such theological practice, if it is to be faithful to Rahner, Barth or Desika, must be deeply pious, self-consciously open to the grace of God, and, as a response to this grace, radically accountable to the needs of "the other," the neighbor and indeed the global community. Sheveland's work exemplifies both virtues, even as it sets broader, interreligious conversations about love and solidarity on a new footing.

Reid B. Locklin

St. Michael's College, University of Toronto

\section{Baby Krishna, Infant Christ. Kristin Johnston Largen. Maryknoll, NY: Orbis Books, 2011, $\mathrm{x}+246$ pages.}

THE subtitle of this clearly written and well organized volume, subtitled A Comparative Theology of Salvation, signals the author's purpose in undertaking her study. Kristin Johnston Largen, who approaches her subject as a Lutheran theologian, is not simply interested in comparing Christ and Krishna and the ways they offer salvation to their followers. Rather, she wishes to help North American Protestants expand their notions of the divine by gaining an appreciation for the Hindu deity Krishna, whose life and meaning are elucidated in light of the more familiar figure of Christ.

The book opens with an Introduction that ushers in the two persons of the study, and lays out a helpful road map for the rest of the work. Chapter One deals with the emerging discipline of Comparative Theology: the author's understanding of it, a defense for its existence in the life of the Christian church, and the possible benefits for Christians who engage this discipline. Part I of the book follows, with two chapters focusing on Krishna. After a brief overview of Hinduism, Krishna's life is described, with an emphasis on his childhood. Then comes a discussion of how Krishna saves his followers, through play (lila), loving devotion (bhakti), and the revelation of the true nature of reality (samsara) from which he offers liberation (moksha).

Part II, also consisting of two chapters, concerns Jesus Christ. The infancy and youth narratives in the Bible are covered, and then the author turns to the non-canonical, apocryphal gospels, where there is much more material concerning the infancy, childhood and youth of Jesus. Stories from the Infancy Gospel of James and the Infancy Gospel of Thomas are related and discussed. Parallel to Part I, the second chapter of Part II discusses how Jesus saves his disciples. An overview of some of the crucial fourth and fifth century Christian debates about the nature and work of Jesus christ is provided, with a discussion of how the birth narratives in the New Testament relate to them. This section on Christian orthodoxy is followed by an interesting foray into the possible theological implications of the childhood narratives in the Infant Gospels of James and of Thomas. Largen here argues that these non-canonical works help us imagine a God who is at play - "a God who is spontaneous, impulsive and inventive" (133) - and a God of emotion - one who, for example, is angry "at those who would exploit and oppress the poor" (144).

Part III, consisting of the two final chapters, considers the adult lives of Krishna and Jesus, and what Christians can learn from material outside the Bible, whether in the Hindu religious tradition or in non-canonical gospels. Largen examines the role of the adult divinities in the lives of their followers, and how some of the themes from the infancy and childhood narratives are developed in the stories from adulthood, while others are dropped. The author discusses Krishna's important role in the Mahabharata and especially the Bhagavad Gita, and what the adult Krishna expects of his followers and how he saves them. Similarly Largen deals with the ministry, death and resurrection of Jesus, and what these mean for the lives and the salvation of his followers. The final chapter of the book sums up lessons that (Protestant) Christians can learn from a study of Krishna and the non-canonical Jesus.

It is important to keep in mind that this book is meant for an audience of committed 